\title{
The Complexity of Realizing Good Governance in Public Services
}

\author{
Dwi Indah Yuliani Solihin, Arifin Tahir, Yanti Aneta, Juriko Abdussamad
}

Public Administration, Gorontalo State University, Indonesia

\begin{abstract}
This particular article aims to analyze and describe: the complexity of realizing good governance in public services. The research method used is the qualitative method. The data analysis in the qualitative research uses an interactive model comprising three analysis components which are: 1) Data reduction, 2) Data presentation, and 3) Data verification and conclusion drawing. The findings indicate that punctuality in service delivery is affected by apparatuses' physiological (physical and mental) abilities. Physiological abilities can be measured through 1) Attitudes. The success in service delivery rests on all people engaged inservice delivery. Either directly or indirectly, the image of Samsat Gorontalo will be depicted by its service delivery. Taxpayers will judge by the first impression when communicating with the people engaged in service delivery and 2) Attention. When delivering services, staff should consistently pay attention to and understand what is expected by taxpayers. If the public hasy shown enthusiasm in paying taxes, Samsat staff should make the required action immediately to respond to the public enthusiasm.
\end{abstract}

Keywords-Public Service, Realizing Good Governance, Punctual Service Delivery.

\section{INTRODUCTION}

\subsection{Background}

As an executor of governance, the government apparatuses contribute to quality public service delivery and the realization of good governance. The government should manage and equip its apparatuses as human resources and hence delivers quality public services. Technology development, through which the government can use an application which manages human resources, allows it to organize its human resources easily. As a result, all management processes, starting from employee registration, mutation, attendance, and payroll, can be more effectively and efficiently managed.

As mentioned earlier, good governance was used by corporates and convened due to the demand for a concept with which people can build a control system which is relevant to their corporates and professional management. Five major principles in corporate governance are transparency, accountability, fairness, responsibility, and responsiveness (Nugroho, 2014:216).

One of the standards for successful public service delivery in Samsat is punctuality. Taxpayers will be satisfied when the public service delivery in Samsat is effective and efficient. Punctuality in delivering services will impact the cost measurement. The more efficient service delivery is, the lower the cost spent. Therefore, punctuality measurement becomes pivotal if properly conducted. Several cases regarding human resources cannot be directly identified using cost analysis. Effectiveness is a subject leading to productivity and efficiency. To measure the effectiveness of a function, we need a measurement related to time, quality, and quantity.

Customer satisfaction is strongly connected to a quality service delivery, as argued by Tjiptono (1996:56) that quality breeds a strong linkage to customer satisfaction. Also, Tjiptono (2012:147) clarifies that customers feel satisfied after identifying an equal comparison between a perceived performance or pay-off of service and their expectation. Any customer desires for satisfaction when receiving a service. According to Ratminto and Atik (2005:28), the standard for successful service delivery is customer satisfaction which is determined by punctuality. Customer satisfaction is when customers elicit the services they need and expect. Referring to the arguments aforementioned, we come to the conclusion that a quality service delivery requires a totality of service delivery concept which covers all service delivery aspects, and that the standard for a quality service delivery is customer satisfaction. 
Samsat stands for Sistem Administrasi Manunggal Satu Atap (One-stop Administrative System). This institution constitutes a public service unit which arranges the registration and identification of motor vehicles, payment of motor vehicle tax, a transfer fee of motor vehicle ownership, and payment of SWDKLL (Sumbangan Wajib Dana Kecelakaan Lalu Lintas, the Compulsory Contributions from Vehicle Owners to Cover the Victims of Traffic Accidents). The services are managed in an integrated and coordinated manner. Implementing the manner, Samsat manages all activities by the means of an integrated application which can organize computation, procedures and mechanisms, working groups, and information and communication systems. Implementing its tasks, Samsat is under the Joint Instruction of the Ministry of Defense, the Ministry of Home Affairs, and the Ministry of Finance No. 6/IMK/0.14/1999 on Samsat Implementation. Not an asset of a certain institution, Samsat is the state asset and consists of three executors that are Polri, Dispenda, and PT (Persero) Jasa Raharja.

The One-stop Administrative Office of Samsat is established to smoothen and speed up its public service delivery whose activities are done in one building. Three institutions, with different authorities and functions, work in the building together. The institutions are the Indonesian National Police responsible for traffic affairs, Local Financial Management Subunit engaging in tax collection, and Jasa Raharja Insurance Service which is authorized to manage the collection of compulsory contributions from vehicle owners to cover the victims of traffic accidents (Perpres No. 5/2015).

Based on our preliminary observation regarding the public service delivery in Samsat of Gorontalo, its tax collection is still poor. We underlie the evidence by the level of community awareness of and participation in the payment of motor vehicle tax. Besides, poor socialization conducted by Samsat brings about ignorance between communities to pay taxes, resulting in futility in achieving targets which have been determined by Samsat of Gorontalo. Furthermore, the police and Samsat should perform active raids and thus give deterrence effects to the community who makes late tax payment. In addition, Samsat of Gorontalo should optimize its tax service delivery by delivering professional, quality, transparent, effective, and efficient tax services. Running a public service delivery should be accompanied by an optimal improvement, ensuring effective public service delivery and responding to the challenges regarding professional public service delivery.
Based on the data we manage to collect, in 2014, Samsat of Gorontalo set the target tax revenue by IDR61,547,326,440.00 (sixty-one billion five hundred and forty-seven million three hundred and twenty-six thousand four hundred and forty Rupiahs). Meanwhile, the actual tax revenue was IDR58,329,358,027.00 (fifty-eight billion three hundred and twenty-nine million three hundred and fifty-eight thousand twenty-seven Rupiahs). The achievement, which was $94.77 \%$, did not reach the target. The target tax revenue in 2015 was then IDR68,215,209,120.00 (sixty-eight billion two hundred and fifteen million two hundred and nine thousand one hundred and twenty Rupiahs). Moreover, the actual tax revenue in 2015 was IDR54,469,664,993.00 (fifty-four billion four hundred and sixty-nine million sixty hundred and sixty-four thousand nine hundred and ninety-three Rupiahs). The achievement, which was only $79.85 \%$, did not reach the target (data source: The Financial Agency of Gorontalo, 2018).

Concerning the achievements, the service provider should fulfill the needs of public service users, generating customer satisfaction. An understanding of quality service delivery is thus required. If the public service delivery in Samsat of Gorontalo is acceptable or meets public expectation, the quality of the public service delivery is good and satisfying. If the public service delivery exceeds beyond customers' expectation, the quality of the public service delivery is considered ideal. On the contrary, if the public service delivery does not meet the expectation, the quality of the public service delivery is poor. Therefore, whether public service delivery is good or poor builds upon how a service provider delivers a service which meets public expectations.

\subsection{Research Objectives}

In response to the phenomena previously confirmed, this article aims to analyze and describe the complexity of realizing good governance in public service delivery.

\section{RESEARCH METHODS}

The research method used is the qualitative method. The data analysis used in qualitative research is an interactive model consisting of three analysis components which are: 1) data reduction, 2) data presentation, and 3) data verification and conclusion drawing (Miles and Huberman, 1992).

The key informants of this research are: 1) the head of UPTD Samsat of Gorontalo as the technical 
director who manages the public service delivery in Samsat, 2) the head of Jasa Raharja and the staff, 3) Dirlantas Polda Gorontalo and the staff, 4) the Financial Agency of Gorontalo and the staff, and 5) taxpayers as service users.

\section{RESEARCH FINDINGS AND DISCUSSION}

Punctuality is considered the expected level of excellence in terms of public service delivery. Service quality is not determined by the service providers but the customers (service users). Customers are those who consume and assess the services delivered so their perceptions determine service quality.

The government, fundamentally, is the public service provider. It is not obliged to deliver services to itself but to the public. Besides, the government should create a condition in which any community member can develop their abilities and creativity for the sake of joint objectives. Considering the obligation, the public bureaucracy must be responsible for delivering public services in a good and professional manner. Public service delivery is the activity of delivering services needed by people or a community in accordance with the regulation and procedures determined.

If the services in Samsat of Gorontalo meet public expectations, the quality of the services is considered good and satisfying. If the public service delivery exceeds beyond customers' expectation, the quality of the public service delivery is considered ideal. On the contrary, if the public service delivery does not meet the expectation, the quality of the public service delivery is poor. Therefore, whether public service delivery is good or poor rests on how a service provider delivers a service which meets public expectation.

We assume that the punctuality of the service delivery in Samsat of Gorontalo is more efficient, considering the advanced information and communication technology. Likewise, punctuality is a pivotal aspect ofservice delivery. If employees are able to deliver good service consistently, the community can feel satisfied.

One of the standards for successful public service delivery in Samsat is punctuality. Taxpayers will be satisfied when the effectiveness and efficiency of public service delivery are realized by Samsat. Delayed service delivery will impact cost measurement. The more efficient the service is, the more the cost can be saved. Punctuality is one of the pivotal aspects if used properly. Several cases regarding human resources indicate that there is no engagement with cost analyses made. Effectiveness is an aspect which leads to productivity and efficiency. To measure the effectiveness of a function, we require measurement of time, quality, and quantity.

Based on our interview with one of the research respondents or taxpayers, the service delivery procedure in Samsat is good and follows the Standard Operating Procedures (SOP) used. There are four counters to where taxpayers should go to finish the process. However, they suggest Samsat add two or three more counters. This aims to make a tax payment service delivery more efficient. In this practical era, the community is spoiled by technology, such as the Internet and mobile phones. Today, we can order anything using the Gojek or Grab application. Considering the efficiency, taxpayers expect to pay taxes using a similar application. However, the method is not easy to implement as more intense socialization should be given to the community. Besides, among the motor vehicle drivers, there must be those with not-updated technology and thus they will find difficulties in making an application-based tax payment. Despite the challenges, public service delivery should constantly make innovations to respond to era advancement.

Furthermore, another informant also reveals that Drive-Thru service delivery is punctual. The Drive-Thru service delivery program is one of the preeminent services regarding motor vehicle tax payment given by the joint office of Samsat of Gorontalo. The program is designed to provide efficiency for taxpayers when they are paying their motor vehicle taxes. Therefore, taxpayers expect punctuality in this program. The standard service delivery time in terms of motor vehicle tax payment is 30 minutes. The service delivery is considered punctual and does not exceed the standards which have been set. To maintain this achievement, we suggest taxpayers with limited time use the Drive-Thru service delivery instead of queuing in the counters. Meanwhile, customer satisfaction is strongly connected to the quality of the service delivered, as confirmed by Tjiptono (1996:56) that quality nurtures a strong linkage to customer satisfaction. Besides, Kotler (in Tjiptono, 1996:147) conveys that customer satisfaction is when customers feel satisfied after identifying an equal comparison between a perceived performance or pay-off of service and their expectation.

Furthermore, our findings indicate that employees' responsiveness contributes to punctual service delivery and therefore, Samsat of Gorontalo should elevate it. Besides, another standard for successful public service delivery in Samsat of Gorontalo is the accuracy of the service delivery. A punctual service delivery, according to our paradigm, can be achieved by preventing any process that may trigger faults. If Samsat of Gorontalo can 
mitigate faults, taxpayers (the community) will be satisfied.

Samsat should meet the expectation of service receivers or taxpayers as their satisfaction is one of the normative standards for good public service delivery. Accurate service delivery is one of the methods with which Samsat of Gorontalo fulfills what the community needs. Besides, service delivery has been equipped with sophisticated systems and technology, allowing effective and efficient service delivery.

According to the head of UPTD Samsat of Gorontalo, Samsat manages three service delivery units which are the police who manage correspondences regarding motor vehicles, Jasa Raharja which organizes insurance affairs, and the provincial civil servants as the service providers who enhance the service delivery in Samsat of Gorontalo. The three components are synergized to provide optimal services for the community. Due to the synergy, when one of the three organizations is running inefficiently, the service delivery in Samsat will get impacted. People may have an understanding that Samsat is under the authority of the local government of Gorontalo so when their complaints, if any, will be applied to the governor.

Furthermore, the employee's responsiveness has an impact on service delivery punctuality. We collect some evidence regarding employees' responsiveness based on the interview with several informants who describe an easy service delivery yet they have to take a long queue in the counters. Besides, they regret Samsat employees' ignorance. Our informants add that administrative requirements should be clearly listed in the front door so they do not need to repeatedly come there. The list is needed due to their inability to memorize the requirements although they consistently pay taxes every year.

Meanwhile, other respondents which come from the community imply that in general, Samsat has made progress in their service delivery. They mention a facility specially provided for the disabled. Besides, they also give a reminder that Samsat must not be satisfied by the progress as other challenges which accompany the era development may come. Samsat should make other innovations or adopt the service delivery system implemented by banks or other private corporates.

Sinambela (2006:5) proposes that public service delivery is the fulfillment of the community's needs and expectations by the state administrators. Besides, according to the Law Number 25 of 2009 on Public Services, public service delivery is an activity or a series of activities which aims to fulfill the needs for services in accordance with the statutory provision for each citizen and resident for goods, services, and/or administrative services organized by public service providers.

In regards to the Law, we conclude that quality services are the services delivered in accordance with the service standards. The essential goal of public service delivery is customer satisfaction. A quality public service can be assessed through the service delivery process and product. An evaluation of service quality can be regarded as the measurement of service quality in a certain period. We certainly need an in-depth analysis to examine the performances of the relevant institutions.

The above explanation underpins our conclusion that successful service delivery greatly rests on the level of customer satisfaction whose one of the factors is punctuality. Customer satisfaction is achieved when customers are delivered services as expected and needed. As such, we need an understanding of the service quality concept.

In regard to the good governance concept in public service delivery, we argue that its punctuality is affected by apparatuses' physiological (physical and mental) abilities when delivering services. The physical abilities can be measured through 1) Attitude. Attitude is a pivotal aspect, as a successful service offering is built upon who engages in it. Either directly or indirectly, the image of Samsat of Gorontalo will be depicted by its service delivery. Taxpayers will certainly memorize the first impression of engaging with the employees involved in the service delivery; and 2) Attention. Attention is also crucial because when delivering services, the responsible employees should pay attention and observe what taxpayers need. When the community has shown enthusiasm in paying taxes, Samsat employees should immediately pick the ball and serve them.

We believe that a punctual service delivery comes with various definitions and indicators since they greatly rely on the respective individuals with various physiological abilities. Several taxpayers perceive a good service delivery and feel satisfied; while others do not. Accordingly, the head of Samsat should concern his/her apparatuses' physical and mental conditions when they are delivering services in Samsat of Gorontalo. 
The Complexity in Realizing Good Governance in a Public Service Delivery

\begin{tabular}{|c|c|c|c|c|c|}
\hline \multirow{3}{*}{ No. } & \multirow{3}{*}{$\begin{array}{c}\text { Aspect } \\
\text { Assessed }\end{array}$} & \multicolumn{4}{|c|}{ Research Findings } \\
\hline & & \multicolumn{2}{|c|}{ Plus } & \multicolumn{2}{|r|}{ Minus } \\
\hline & & Finding & Impact & Finding & Impact \\
\hline & \multirow[t]{2}{*}{ Punctuality } & $\begin{array}{l}\text { Time utilization is } \\
\text { effective and } \\
\text { efficient, }\end{array}$ & $\begin{array}{l}\text { Customer } \\
\text { satisfaction }\end{array}$ & $\begin{array}{l}\text { The quality of } \\
\text { service delivery } \\
\text { depends on the } \\
\text { service } \\
\text { providers' } \\
\text { abilities, }\end{array}$ & $\begin{array}{l}\text { Although customer } \\
\text { satisfaction is one of the } \\
\text { standards for successful } \\
\text { service delivery, it } \\
\text { cannot be objectively } \\
\text { measured. }\end{array}$ \\
\hline & & $\begin{array}{l}\text { Technology sustains } \\
\text { employees in } \\
\text { working. }\end{array}$ & $\begin{array}{l}\text { Optimal } \\
\text { performance } \\
\text { of Samsat }\end{array}$ & - & - \\
\hline
\end{tabular}

The Elaboration of the Research Findings

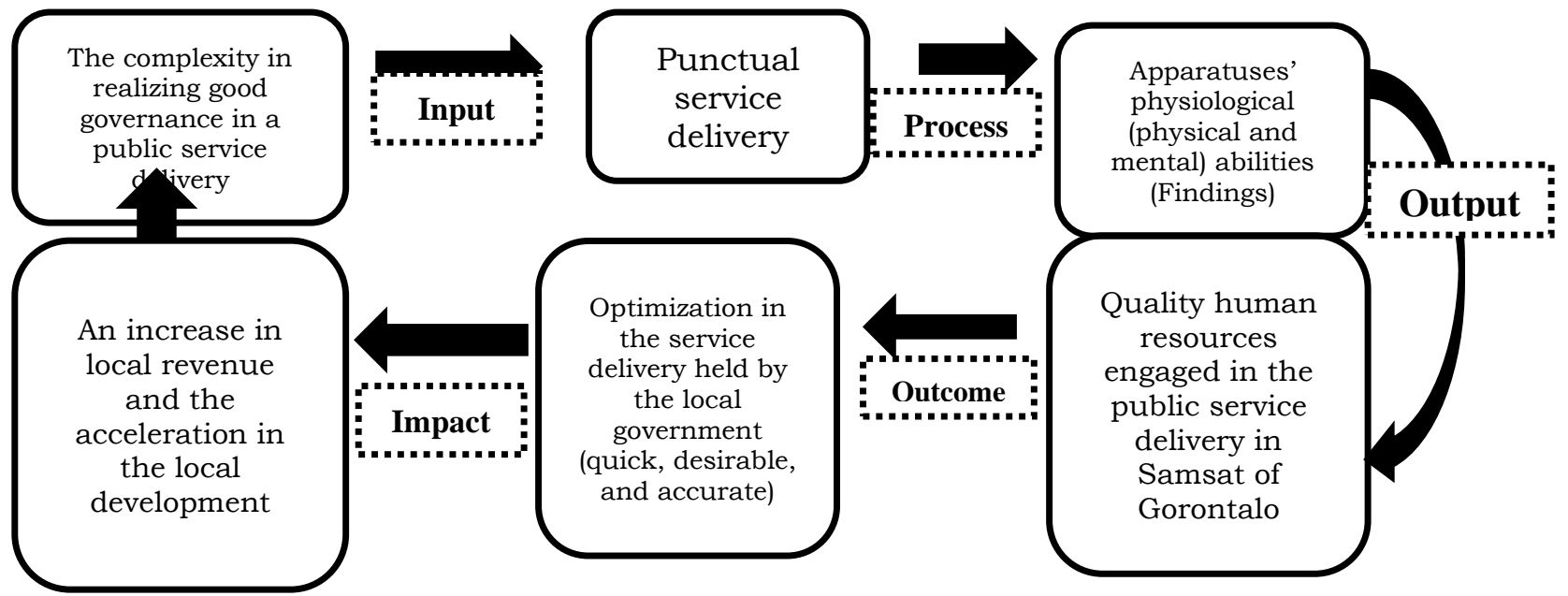

Based on the research findings and discussion, we propose the following solutions to the realization of good governance in the public service delivery in Samsat of Gorontalo.

\section{Commitment to Quality (Facilities, Cooperation, and Socializations)}

The joint office of Samsat is occupied by the police of the Republic of Indonesia which manages traffic affairs and is represented by Dirlantas Polda, the Local Financial Management Subunit which is responsible for tax collection at the provincial level and represented by the Revenue Service (Dispenda), and a business entity which contributes to Samsat (PT. Jasa Raharja). When implementing their tasks and functions, the respective apparatuses should build upon high awareness to give the fundamental meaning of the commitment to quality in accordance with the statutory provision. Apparatuses' good attitudes are shown by the following characteristics: being honest, reliable, rigorous, disciplined, effective, efficient, creative, innovative, respectful, polite and friendly, and fair (indiscriminative), sincere, nurturing high integrity, and maintaining their reputation. Apparatuses' good attitudes will certainly lead to good work culture and hence good corporate governance.

We have designed the criteria for the determination of the commitment to quality as follows:

1. The commitment to quality is a shared and fixed cultural value. Work culture constitutes the pattern of attitudes or work styles implemented by an organization for generations. Good work culture is aimed to elevate the effectiveness and efficiency in resource utilization, prompt apparatuses' imagination 
and creativeness to bring about innovative service delivery, and generate a value-added for all stakeholders. To implement a good work culture, the employees of Samsat of Gorontalo can start it by nurturing discipline.

2. A quality public service delivery significantly contributes to the more prosperous, fairer, and inclusive (accessible) milieu and community. The current contribution of Samsat of Gorontalo is to enhance the Locally-generated Revenue (PAD) through taxes to protect community welfare and create a condition which supports social and economic development.

\section{CONCLUSION}

The research findings indicate that punctuality in service delivery is affected by apparatuses' physiological (physical and mental) abilities in terms of service delivery. The physiological abilities are measured through 1) Attitude. Attitude is a pivotal aspect, as a successful service offering is built upon who engages in it. Either directly or indirectly, the image of Samsat of Gorontalo will be depicted by its service delivery. Taxpayers will certainly memorize the first impression of engaging with the employees involved in the service delivery; and 2) Attention. Attention is also crucial because when delivering services, the responsible employees should pay attention and observe what taxpayers need. When the community has shown enthusiasm in paying taxes, Samsat employees should immediately pick the ball and serve them.

\section{REFERENCES}

[1] Atik and ratminto. 2005. Manajemen pelayanan, disertai dengan pengembangan model konseptual, penerapan citizen's charter dan standar pelayanan minimal. Yogyakarta: Pustaka Pelajar

[2] Kotler, Philip and Kevin Lane Keller. 2009. Marketing Management, Jilid 13. Singapore. Pearson Prentice Hall

[3] Miles and Huberman. 1992. Analisis Data Kualitatif (translated by Ole Tjetjep Rohedi Rosidi). Jakarta: Universitas Indonesia.

[4] Nugroho, Riant. 2014. Public Policy. Jakarta: PT. Elex Media Komputindo.

[5] Sinambela, Lijan.P. 2016. Reformasi Pelayanan Publik. PT Bumi Aksara:Jakarta.

[6] Tjiptono, Fandy. 2012. Service Management Mewujudkan Layanan Prima. Yogyakarta: CV Andi Offset.

[7] Law Number 25 of 2009 on Public Services.

[8] Presidential Decree No. 5/2015 on Compulsory Traffic Accident Fund Contribution.
[9] Joint Instruction of the Ministry of Defense, Ministry of Home Affairs, and Ministry of Finance No. 6/IMK/0.14/1999 on Samsat Implementation. 